\title{
Bottomland hardwood forest growth and stress response to hydroclimatic variation: evidence from dendrochronology and tree ring $\Delta^{13} \mathrm{C}$ values
}

\author{
Ajinkya G. Deshpande ${ }^{1}$, Thomas W. Boutton ${ }^{1}$, Ayumi Hyodo ${ }^{1}$, Charles W. Lafon ${ }^{2}$, and Georgianne W. Moore ${ }^{1}$ \\ ${ }^{1}$ Department of Ecology and Conservation Biology, Texas A\&M University, College Station, TX, 77843, USA \\ ${ }^{2}$ Department of Geography, Texas A\&M University, College Station, TX, 77843, USA
}

Correspondence: Ajinkya G. Deshpande (ajinkyagd@tamu.edu)

Received: 12 April 2020 - Discussion started: 28 April 2020

Revised: 5 August 2020 - Accepted: 13 October 2020 - Published: 19 November 2020

\begin{abstract}
Wetland forests around the world have been reduced to a small proportion of their original expanse due to changing climatic conditions and intensification of human land use activities. As a case in point, the Columbia bottomland hardwood forests along the Brazos-Colorado coastal basin on the Gulf coast of Texas are currently threatened by an increasingly erratic hydroclimate in the form of both extreme floods and droughts and by urban expansion. In this study, we use dendrochronology and tree ring carbon isotopes to understand the effect of changing hydroclimatic conditions on the functional attributes of these forests. We examined the tree rings of Quercus nigra at four sites within the Columbia bottomlands, of which one site experiences frequent and prolonged flooding, while the other three are less flood prone. The objectives of this study were to (i) understand the impact of hydroclimatic variation on radial growth, using tree ring width analysis, (ii) assess the magnitude of physiological stress inflicted by extreme hydroclimatic conditions, using tree ring $\Delta^{13} \mathrm{C}$ measurements as a proxy, and (iii) evaluate the relationship between tree ring width and $\Delta^{13} \mathrm{C}$ values. Radial growth across the landscape was influenced most strongly by the midgrowing season climate, while the early growing season climate had the strongest effect on $\Delta^{13} \mathrm{C}$. Growth inhibition was minimal, and tree ring $\Delta^{13} \mathrm{C}$ values were not affected in trees at the wetter site under extreme hydrological conditions such as droughts or floods. In addition, trees at the wet site were less sensitive to precipitation and showed no response to higher temperatures. In contrast, trees at the three drier sites experienced growth inhibition and had lower tree ring $\Delta^{13} \mathrm{C}$ values during dry peri-
\end{abstract}

ods. Our results indicate more favorable growing conditions and lower stress in trees growing under wetter hydrological conditions. Management and conservation strategies dependent on site-specific conditions are critical for the health of these wetland forests under a rapidly changing hydroclimate. This study provides the first dendrochronological baseline for this region and a better understanding of favorable conditions for the growth and health of these forests, which can assist in management decisions such as streamflow regulation and conservation plans.

\section{Introduction}

Wetland forests are subjected to drought and floods, both of which can alter productivity and cause physiological stress in plants (Miao et al., 2009; Vivian et al., 2014). Climate extremes and warming are predicted to increase in the $21 \mathrm{st}$ century across southern North America (Seager et al., 2007). Bottomland hardwood forests, a common wetland forest type, cover a significant proportion of the floodplains of the rivers and bayous in coastal regions of the southeastern USA. Along the upper Texas Gulf coast, the lower basins of the Brazos, San Bernard and Colorado rivers combine to form the Columbia bottomland hardwood forests, an area of high biodiversity with a critical role in regional hydrology. Large portions of the Columbia basin forest have been cleared, and land cover is now a mix of isolated forest patches, cropland and pasture (Griffith et al., 2004), with only a few larger forest patches remaining (Fig. 1a). The presettlement distribu- 
tion of these forests was $>283000$ ha along a $150 \mathrm{~km}$ long corridor inland from the coast but has since been reduced to about 72000 ha (USFWS, 1997; Barrow and Renne, 2001; Barrow et al., 2005). In the last few decades, this ecosystem has been experiencing dramatic hydrologic variation caused by severe droughts (Schmidt and Garland, 2012; Hoerling et al., 2013; Moore et al., 2015) and floods (van Oldenborgh et al., 2017; Sebastian et al., 2019), altering hydrologic conditions over short temporal scales. Annual precipitation amounts have been highly variable, with up to $61 \%$ more rainfall than average during some years, while there is up to $53 \%$ deficit during others, in addition to at least five major tropical storms and hurricanes. Rapid urbanization caused by the proximity to the city of Houston and increasing agricultural activity in the area have likely altered water cycling significantly in these forests (Kearns et al., 2015; TWDB, 2017). Similar forcing factors have altered the state of most wetland forest types in southeastern USA.

Dendrochronology, the study of tree rings, has been extensively used to understand the response of forest growth to changing environmental conditions (Babst et al., 2013; Charney et al., 2016; Tei et al., 2017). Additionally, tree ring carbon isotopic composition is an indirect record of internal leaf $\mathrm{CO}_{2}$ concentration, which is controlled by a balance between stomatal conductance and photosynthetic rate in response to environmental conditions (Farquhar et al., 1989; McCarroll and Loader, 2004; Gessler et al., 2014) such as temperature, vapor pressure and precipitation (Robertson et al., 1997; Leavitt et al., 2002). As tree rings are distinguished by their high temporal (annual or subannual) and spatial resolution, regional tree ring chronologies and carbon isotopic values have the potential to identify a wide range of growth and stress responses of vegetation to hydroclimatic variability. However, carbon isotopic composition of tree rings $\left(\delta^{13} \mathrm{C}\right)$ is also influenced by the changing carbon isotopic composition of atmospheric $\mathrm{CO}_{2}$. The increase in atmospheric $\mathrm{CO}_{2}$ concentration, mainly due to fossil fuel combustion, has led to a significant decrease in $\delta^{13} \mathrm{C}$ of atmospheric $\mathrm{CO}_{2}$ over the last century (Graven et al., 2017). Although this change is relatively small over short temporal scales, this signal should be removed from tree ring records when using tree ring $\delta^{13} \mathrm{C}$ to understand plant physiological responses to local conditions. Changes in carbon isotopic composition of atmospheric $\mathrm{CO}_{2}$ can be accounted for by converting tree ring carbon isotope ratio $\left(\delta^{13} \mathrm{C}\right)$ to carbon isotope discrimination $\left(\Delta^{13} \mathrm{C}\right.$; Farquhar, 1983). Tree ring $\delta^{13} \mathrm{C}$ values are inversely related to $\Delta^{13} \mathrm{C}$ values as higher discrimination results in a lower $\delta^{13} \mathrm{C}$ ratio.

Studies conducted across the globe demonstrate growth inhibition signals in the form of narrow tree rings in response to drought (Fang et al., 2011; Au and Tardif, 2012; Wang et al., 2017; Gao et al., 2018; Mikac et al., 2018; Szejner et al., 2020). Through these studies, a strong positive relationship between growth rates and precipitation has been well established. However, tree growth is also known to be af- fected by waterlogging and flooded soils (Astrade and Bégin, 1997; Kozlowski, 1997; St. George, 2014). These effects are more difficult to detect in tree ring patterns, and therefore, very few studies have evaluated growth responses to flooding (Ballesteros-Canovas et al., 2015; Therrell and Bialecki, 2015; Meko and Therrell, 2020), particularly in southeastern USA (LeBlanc and Stahle, 2015).

Lower $\Delta^{13} \mathrm{C}$ values of tree ring cellulose usually reflect stress caused by low environmental moisture at the time of carbon fixation, while higher $\Delta^{13} \mathrm{C}$ values are indicative of nonstressful growing conditions (Ehleringer et al., 1993; Saurer et al., 1995). Thus, dendroisotopic approaches combine the advantages of precisely dated and annually resolved tree rings with the sensitivity of the carbon isotopic composition governed by ecophysiological responses to the environment (Gessler et al., 2009; Gessler et al., 2014). However, trees growing in wetland settings may not respond solely to a moisture deficit. Excessive levels of precipitation and prolonged inundation or saturation in wetland ecosystems can also result in reduced stomatal conductance in trees, resulting in low discrimination values; however, this effect is highly variable across species (Stuiver et al., 1984; Ewe and Sternberg, 2002; Ewe and Sternberg, 2003; Anderson et al., 2005; Buhay et al., 2008; Voelker et al., 2014). Studies in wetlands attribute this positive relationship between tree ring carbon isotopes and precipitation to excess water stress. Although debatable, a number of possible mechanisms have been suggested with significant evidence to support this relationship. These include the disruption of water and nutrient uptake due to anoxic conditions in the root zone (Jackson and Drew, 1984), lowered root hydraulic conductivity (Davies and Flore, 1986), increased abscisic acid concentrations (Kozlowski and Pallardy, 1984) and accumulation of metabolic toxins from flooding (Jackson and Drew, 1984). Additionally, higher evaporation rates at wetland sites where ponding is common can reduce vapor pressure deficit in the canopy, resulting in lower canopy conductance (Oren et al., 2001) and, subsequently, lower discrimination rates. Anaerobic conditions at waterlogged sites can also lead to isotopically depleted methane production from the soils and affect the ambient $\delta^{13} \mathrm{C}$ in the canopy (Fisher et al., 2017). If these conditions that are specific to wetland ecosystems persist over a longer period during the growing season, carbon isotopic composition of tree rings can be influenced.

In this study, we investigated how bottomland hardwood wetland forests of eastern Texas, USA, respond to hydroclimatic variation and extremes under different edaphic conditions. The study was conducted at four sites of which one was a frequently flooded wet site, while at the other three sites waterlogging and surface flooding were much less frequent and more ephemeral. Our first objective was to understand how radial growth is affected by hydroclimatic variation using tree ring width analysis in water oak (Quercus nigra L.), a dominant species in the Columbia bottomland hardwood forest. We hypothesized that, at relatively drier 


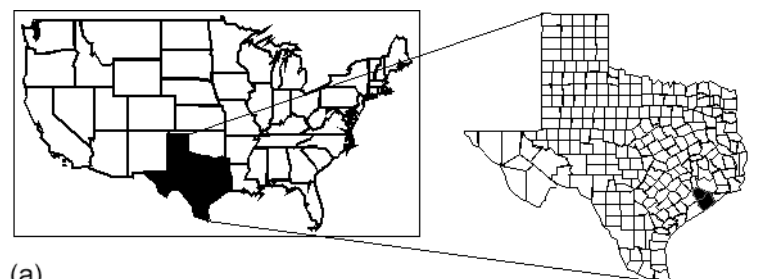

(a) 道要

(b)

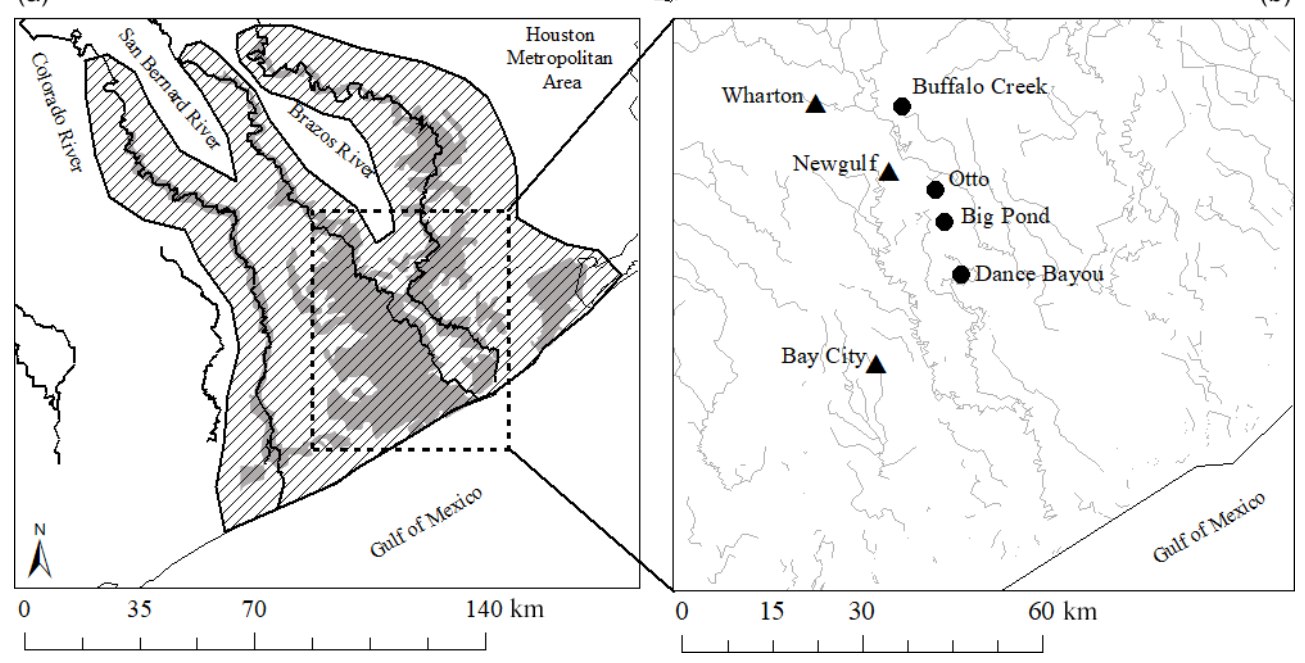

Figure 1. (a) Current distribution of the Columbia bottomlands (gray) and the historic extent shown by the slanted parallel lines (USFWS, 1997; Houston Wilderness, 2007; Rosen et al., 2008). The area in which the study sites are located is shown by the box with a dashed line. (b) Locations of study sites (circles) and weather stations (triangles) in the Brazos-Colorado coastal basin.

sites, trees have lower growth rates on average over long timescales compared to wetter sites. Periods of higher rainfall will be associated with increases in growth. However, in extremely wet conditions at the frequently waterlogged site, trees will show a decline in growth caused by flooding and hypoxic conditions. Our second objective was to assess tree ring $\Delta^{13} \mathrm{C}$ as an indicator of physiological stress inflicted by hydroclimatic conditions on these forests. We hypothesized that tree ring $\Delta^{13} \mathrm{C}$ in trees growing under relatively drier soil conditions will increase during periods of higher rainfall. In contrast, the opposite trend is expected at the wetter site, where increasing moisture would induce flooding stress. In addition, we hypothesized that trees growing where waterlogging is common are less stressed during dry periods than those at the drier sites because of the slower depletion of soil water reserves. Our third objective was to evaluate the relationship between physiological stress and growth inhibition. Although a positive relationship between tree ring $\Delta^{13} \mathrm{C}$ and growth (tree ring width) is expected in this study, the strength of this relationship could vary with site conditions. Given that water oaks that are moderately tolerant of flooding and dry conditions are also common in this ecosystem, we hypothesized that drought stress had a stronger effect on growth than flooding stress. Thus, we expected a stronger negative effect of physiological stress on growth at drier sites.

\section{Materials and methods}

\subsection{Study area description}

The study was conducted at four different sites located within the Brazos-Colorado coastal basin in the San Bernard National Wildlife Refuge, Brazoria and Fort Bend counties, Texas. The four sites are Dance Bayou (DB), Big Pond (BP), Otto (OT) and Buffalo Creek (BC; Fig. 1b; Table 1). Site DB was observed to be flooded most frequently after significant rain events from 2016 to 2019. This site also remained waterlogged, unlike the other three sites. Therefore, we refer to this site as the "wet site". The sites are located in Ecoregion III (western Gulf coastal plain) and Ecoregion IV (floodplain and low terraces), which are dominated by mixed bottomland hardwood forests (Griffith et al., 2004) at an elevation of about $16 \mathrm{~m}$ above mean sea level (MSL). Dominant tree species at these sites include Quercus nigra L. (water oak), Quercus fusiformis Small (live oak), Celtis laevigata var. laevigata Willd. (sugarberry) and Triadica sebifera (L.) Small (Chinese tallow). The climate of this region is classified as humid subtropical (Cfa) under the Köppen-Geiger climate classification system (Köppen, 1900). The average maximum monthly temperature is approximately $26^{\circ} \mathrm{C}$, and the average minimum monthly temperature is approximately $15^{\circ} \mathrm{C}$. Mean annual rainfall is $1143 \mathrm{~mm}$, with an average relative humidity of $\sim 70 \%$ (NOAA, 2018a). The sites are lo- 
cated in the Linnville Bayou watershed of the San Bernard River basin. As these forests are situated in the floodplain, sloughs are a common occurrence and inundate significant parts of the forest. Streamflow in Linnville Bayou and the adjoining streams and sloughs that traverse the four sites is driven by at least seven dams on the San Bernard River, with heights ranging from 2.5 to $7.5 \mathrm{~m}$ (National Inventory of Dams, 2020). Therefore, the presence of these dams and their varying discharge into Linnville Bayou adds significant complexity to the hydrology of the Columbia bottomlands in addition to an already fluctuating hydroclimate.

Soils are mainly Vertisols and Alfisols dominated by clay, loam and sandy loam texture (NRCS, 2020). The soils series include Aris fine sandy loam, Bacliff clay, Edna loam, Leton loam, Pledger clay and Churnabog clay. In an Earth resistivity tomography study conducted by Guerra (2020) at sites DB, BP and OT, the wetter site (DB) had more conductive soil in the root zone compared to the other two drier sites (Table 1). As all three sites had similar soil salinity, the more conductive soils at site DB are attributed to higher soil moisture.

\subsection{Tree core sampling}

We sampled eight mature $Q$. nigra trees at each site in May 2017. Healthy individuals with no obvious injuries like cavities, scars or diseases were selected. Preference was given to trees with larger diameters at breast height $(>40 \mathrm{~cm})$ and uniform girth (Stokes and Smiley, 1968). Three cores were extracted at breast height from every tree spaced equally around the circumference. Two cores were processed and used for ring width measurements, and the third core was used for $\delta^{13} \mathrm{C}$ analysis after cellulose extraction.

\subsection{Dendrochronology}

Tree cores were dried to a constant weight at $60^{\circ} \mathrm{C}$ and mounted on $9.5 \times 9.5 \mathrm{~mm}$ grooved core mounts. The mounted cores were sanded using a hand sander with progressively finer grades of sandpaper (60 to 400 grit; Speer, 2012). Tree ring widths were visually cross-dated and then measured using MeasureJ2X linked to a sliding-stage microscope $(2.5 \mathrm{x})$. To verify and refine the cross-dating, tree ring widths were statistically assessed using the COFECHA program (Holmes, 1983). Site-level series intercorrelation between individual cores and mean sensitivity obtained from COFECHA were used to determine the quality of crossdating (Grissino-Mayer, 2001; Speer, 2012). Series intercorrelation indicates chronology-to-chronology variation in annual growth within a given chronology group, while mean sensitivity indicates if the variation in annual growth from year to year is sensitive enough for dendroclimatology analyses. As series intercorrelation can be a useful metric for interpreting variations in growth between cores from the same tree, trees within a given site, cores across different sites and trees across different sites, we calculated all four of these parameters separately (Bunn et al., 2008). To calculate series intercorrelation between trees within and across sites, we first averaged the corresponding annual ring widths from multiple cores sampled from the same tree. The final standardized ARSTAN (A) chronology (ring width index RWI) was generated for each site using the ARSTAN program, which mathematically standardizes tree ring series by controlling the autocorrelation component in the time series and maximizes the climate signal (Cook and Holmes, 1984; Speer, 2012). Additionally, we also employed the regional curve standardization (RCS) detrending method to generate site-level RWI using the RCS function (Biondi and Qeadan, 2008) in the dplR R package (Dendrochronology Program Library in R; Bunn et al., 2008). In the RCS detrending method, raw ring width measurements of multiple trees from the same site are aligned by cambial age to calculate the average ring width for each annual ring. An age-related declining curve is then fitted through the measurements, and the ratio of each measurement to the RCS curve value (expected growth) is then calculated to generate a RWI (Erlandsson, 1936; Briffa et al., 1992; Briffa and Melvin, 2011). Unlike in the ARSTAN method in which RWI is generated by aligning ring widths by calendar year, in the RCS detrending method ring widths are aligned by cambial age. We also calculated the basal area increment (BAI) for each tree using the insideout method (Biondi, 1999) in dplR R package (Bunn et al., 2008). Site-level BAI was obtained by averaging the BAI of all trees from the site for each year.

\subsection{Climate data}

Daily climate summaries for 1950-2016 from three weather stations (Bay City, Newgulf and Wharton, Texas, USA; Fig. 1B) were obtained from the National Oceanic and Atmospheric Administration (NOAA) National Centers for Environmental Information (NCEI) database (NOAA, 2018a) and Palmer drought severity index (PDSI) measurement for the Texas upper coast division was collected from the NOAA National Environmental Satellite, Data and Information Service (NESDIS) database (NOAA, 2018b). Monthly and annual averages were used for analyses. As the three weather stations are located at equal distances from the sites $(<25 \mathrm{~km})$, and the measurements are highly correlated, an average of the three records was used for dendroclimatology analyses.

\subsection{Tree ring $\delta^{13} \mathrm{C}$ analysis}

Tree cores not utilized for ring width analyses were handsanded using sandpaper (220 grit) to enhance ring visibility. Tree rings were selected from years with a wide range of precipitation to cover the maximum breadth of the dry-wet hydroclimatic spectrum $\left(235-1120 \mathrm{~mm} \mathrm{yr}^{-1}\right)$. Selected tree rings were precisely excised using an X-Acto knife. For $\delta^{13} \mathrm{C}$ 
Table 1. Site description with basic soil properties (NRCS, 2020) and resistivity measurements averaged over the top $100 \mathrm{~cm}$ depth (Guerra, 2020). Note: Dance Bayou - DB; Big Pond - BP; Otto - OT; Buffalo Creek - BC; diameter at breast height - DBH.

\begin{tabular}{lrlrrrrrrrr}
\hline Site & $\begin{array}{r}\text { Elevation } \\
(\mathrm{m})\end{array}$ & Coordinates & $\begin{array}{r}\text { Tree DBH } \\
(\mathrm{cm}) \\
(\mathrm{mean} \pm \mathrm{SE})\end{array}$ & $\begin{array}{r}\text { Clay } \\
\%\end{array}$ & $\begin{array}{r}\text { Silt } \\
\%\end{array}$ & $\begin{array}{r}\text { Sand } \\
\%\end{array}$ & $\begin{array}{r}\text { Soil } \\
\mathrm{pH}\end{array}$ & $\begin{array}{r}\text { Bulk } \\
\text { density } \\
\left(\mathrm{g} / \mathrm{cm}^{3}\right)\end{array}$ & $\begin{array}{r}\text { Organic } \\
\text { matter } \\
(\%)\end{array}$ & $\begin{array}{r}\text { Resistivity } \\
(\Omega \cdot \mathrm{m}) \\
(\mathrm{mean})\end{array}$ \\
\hline DB & 13 & $\begin{array}{l}29^{\circ} 7^{\prime} 9.56^{\prime \prime} \mathrm{N} \\
95^{\circ} 47^{\prime} 4.24^{\prime \prime} \mathrm{W}\end{array}$ & $48.3 \pm 5.6$ & 33 & 58 & 9 & 7.4 & 1.37 & 1.7 & 9.9 \\
\hline BP & 16 & $\begin{array}{l}29^{\circ} 9^{\prime} 56.66^{\prime \prime} \mathrm{N} \\
95^{\circ} 49^{\prime} 43.34^{\prime \prime} \mathrm{W}\end{array}$ & $58.5 \pm 3.2$ & 71 & 28 & 1 & 7.1 & 1.12 & 4.8 & 16.2 \\
\hline OT & 17 & $\begin{array}{l}29^{\circ} 10^{\prime} 47.76^{\prime \prime} \mathrm{N} \\
95^{\circ} 50^{\prime} 28.65^{\prime \prime} \mathrm{W}\end{array}$ & $56.4 \pm 4.7$ & 71 & 28 & 1 & 7.1 & 1.12 & 4.8 & 12.2 \\
\hline $\mathrm{BC}$ & 26 & $29^{\circ} 19^{\prime} 21.75^{\prime \prime} \mathrm{N}$ & $51.7 \pm 3.8$ & 55 & 34 & 11 & 7.8 & 1.20 & 2.2 & N/A \\
& $95^{\circ} 51^{\prime} 47.01^{\prime \prime} \mathrm{W}$ & & & & & & & & \\
\hline
\end{tabular}

analysis, $\alpha$ cellulose was extracted from the tree rings using a slightly modified version of the Jayme-Wise method (Green, 1963 ) in which a Soxhlet extraction assembly is used (Leavitt and Danzer, 1993; Cullen and Macfarlane, 2005). $\delta^{13} \mathrm{C}$ in tree ring $\alpha$ cellulose was analyzed using a Costech ECS 4010 elemental analyzer (Costech Analytical Technologies, Inc., Valencia, CA, USA) interfaced with a DELTA V Advantage isotope ratio mass spectrometer (DELTA V; Thermo Fisher Scientific, Waltham, MA, USA) operating in continuous flow mode at the Stable Isotopes for Biosphere Science (SIBS) lab, Texas A\&M University (College Station, TX, USA). Tree ring $\delta^{13} \mathrm{C}$ was calculated in $\delta$ notation using the following equation:

$\delta=\left[\frac{R_{\mathrm{SAMPLE}}-R_{\mathrm{STD}}}{R_{\mathrm{STD}}}\right] \times 10^{3}$

where $R_{\text {SAMPLE }}$ is the ${ }^{13} \mathrm{C} /{ }^{12} \mathrm{C}$ ratio of the cellulose sample, and $R_{\mathrm{STD}}$ is the ${ }^{13} \mathrm{C} /{ }^{12} \mathrm{C}$ ratio of the Vienna Pee Dee Belemnite (VPDB) standard (Coplen, 1995). Duplicate measurements taken after every 10 measurements yielded a precision of $\pm 0.1 \%$.

The atmospheric $\delta^{13} \mathrm{C}$ depletion trend over the study period was removed from the tree ring carbon isotopic record by converting carbon isotope ratios $\left(\delta^{13} \mathrm{C}\right)$ to carbon isotope discrimination values $\left(\Delta^{13} \mathrm{C}\right)$ (Farquhar, 1983) as follows:

$\Delta^{13} \mathrm{C}=\left(\delta^{13} \mathrm{C}_{\mathrm{atm}}-\delta^{13} \mathrm{C}_{\text {plant }}\right) /\left(1+\delta^{13} \mathrm{C}_{\text {plant }}\right)$.

Average annual atmospheric $\delta^{13} \mathrm{C}$ values from La Jolla pier, CA, USA (Keeling and Keeling, 2017), were obtained to calculate $\Delta^{13} \mathrm{C}$ (Table 2$)$.

\subsection{Statistical analyses}

To evaluate differences in mean ${ }^{13} \mathrm{C}$ values between sites, we used one-way analysis of variance (ANOVA). Levene's
Table 2. Annual average atmospheric $\delta^{13} \mathrm{C}$ values from La Jolla Pier, CA, USA.

\begin{tabular}{cccccc}
\hline Year & $\delta^{13} \mathrm{C}$ & Year & $\delta^{13} \mathrm{C}$ & Year & $\delta^{13} \mathrm{C}$ \\
\hline 1986 & -7.70 & 1997 & -8.02 & 2008 & -8.34 \\
1987 & -7.77 & 1998 & -8.11 & 2009 & -8.32 \\
1988 & -7.87 & 1999 & -8.13 & 2010 & -8.36 \\
1989 & -7.87 & 2000 & -8.10 & 2011 & -8.38 \\
1990 & -7.89 & 2001 & -8.11 & 2012 & -8.43 \\
1991 & -7.92 & 2002 & -8.14 & 2013 & -8.47 \\
1992 & -7.91 & 2003 & -8.23 & 2014 & -8.51 \\
1993 & -7.89 & 2004 & -8.24 & 2015 & -8.51 \\
1994 & -7.95 & 2005 & -8.26 & 2016 & -8.59 \\
1995 & -8.01 & 2006 & -8.33 & & \\
1996 & -8.03 & 2007 & -8.34 & & \\
\hline
\end{tabular}

test was used to check for equal variances, normality was tested using the Shapiro-Wilk test and post hoc analysis was conducted using Tukey honestly significant difference (HSD). Total monthly precipitation was calculated from daily summaries. Daily maximum temperatures for each day of the month were used to compute mean monthly maximum temperature. Monthly PDSI values were used directly as obtained (NOAA, 2018b). To identify the portion of the growing season that has the strongest influence on growth and tree ring $\Delta^{13} \mathrm{C}$, we used simple linear regressions between site-wise annual ring width index and $\Delta^{13} \mathrm{C}$ against monthly precipitation, mean monthly maximum temperature and monthly PDSI for all months of the same year and the previous year. Additionally, to estimate the multimonth influence of early, late and overall growing season climate on growth and tree ring $\Delta^{13} \mathrm{C}$, we averaged monthly climate data over progressively longer periods of up to 8 months within the growing season. We conducted additional linear regression on these calculated means against the annual ring width index and $\Delta^{13} \mathrm{C}$. The time interval during which cli- 
Table 3. Descriptive statistics of site-level and combined tree ring chronologies generated using COFECHA.

\begin{tabular}{lrrrl}
\hline Chronology & $\begin{array}{r}\text { Number } \\
\text { of trees }\end{array}$ & $\begin{array}{r}\text { Number of } \\
\text { dated } \\
\text { series }\end{array}$ & $\begin{array}{r}\text { Mean } \\
\text { sensitivity }\end{array}$ & $\begin{array}{l}\text { Mean } \\
\text { series } \\
\text { length }\end{array}$ \\
\hline All sites & 32 & 64 & 0.37 & 32 years \\
DB & 8 & 16 & 0.35 & 24 years \\
BP & 8 & 16 & 0.36 & 40 years \\
OT & 8 & 16 & 0.42 & 27 years \\
BC & 8 & 16 & 0.37 & 38 years \\
\hline
\end{tabular}

mate was found to be most strongly influencing growth and tree ring $\Delta^{13} \mathrm{C}$ (maximum coefficient of determination) was used for dendroclimatology analyses. To understand the relationship between growth and stress, we also used linear regression between site-wise annual ring width index and $\Delta^{13} \mathrm{C}$. All statistical analyses were conducted in R ( R Core Team, 2012).

\section{Results}

\subsection{Site chronologies}

Site-level tree ring width chronologies (ARSTAN and RCS) were closely related to precipitation trends. Patterns of RWI and BAI were similar between sites for much of the 40 year period, except for a few wet years $(1983,1991,1992,1997$, 2001, 2003 and 2007; Fig. 2a, b, c), whereas, tree ring $\Delta^{13} \mathrm{C}$ patterns were more variable, with values from site DB being higher in general (Fig. 2d). All site-level chronologies were found to be sensitive enough for dendroclimatological analyses as mean sensitivity, which is a measurement of year-toyear variability in annual growth, fell within an acceptable range (Table 3). Forest stands at sites DB and OT were found to be younger ( 24 and 27 years, respectively) than the other two sites, as indicated by the mean series lengths (Table 3 ). High series intercorrelations for the drier sites indicate lower within and between tree differences at these sites, as compared to the wettest site of DB (Table 4). Series intercorrelations across and within sites were slightly lower when calculated using tree level means (Table 4). Ring width indices calculated using the RCS and ARSTAN detrending methods were strongly correlated for all four sites (DB $-p<0.0001$; $R^{2}=0.71 ; \mathrm{BP}-p<0.0001 ; R^{2}=0.93 ;$ OT $-p<0.0001$; $R^{2}=0.82 ; \mathrm{BC}-p<0.0001 ; R^{2}=0.92$; Fig. 3 ). BAI at all four sites increased at a slow rate until the year 2000, after which an increasing shift was observed. At site DB, BAI increased more sharply, possibly due to the stand being relatively younger, while at site BP, which had the most mature stand, the change in BAI over time was less variable (Fig. 2c).
Table 4. Series intercorrelation values calculated using chronologies from individual cores and tree level means across all sites and within each site.

\begin{tabular}{lrrrr}
\hline Chronology & $\begin{array}{r}\text { Across } \\
\text { all sites } \\
\text { (individual } \\
\text { cores) }\end{array}$ & $\begin{array}{r}\text { Across } \\
\text { all sites } \\
\text { (tree } \\
\text { means) }\end{array}$ & $\begin{array}{r}\text { Within } \\
\text { site } \\
\text { (individual } \\
\text { cores) }\end{array}$ & $\begin{array}{r}\text { Within } \\
\text { site } \\
\text { (tree } \\
\text { means) }\end{array}$ \\
\hline All sites & 0.64 & 0.59 & - & - \\
DB & - & - & 0.61 & 0.51 \\
BP & - & - & 0.70 & 0.65 \\
OT & - & - & 0.79 & 0.67 \\
BC & - & - & 0.68 & 0.66 \\
\hline
\end{tabular}

\subsection{Differences in site-level tree ring $\Delta^{13} \mathrm{C}$ values}

Comparison between site-level mean tree ring $\Delta^{13} \mathrm{C}$ measurements averaged over the entire 40-year study period supports our second hypothesis. Tree ring $\Delta^{13} \mathrm{C}$ measurements were different between sites when averaged over the 40-year period (one-way ANOVA; F $(3,24)=4.05 ; p=0.01$ ). This indicates that at least one site has a significantly different mean $\Delta{ }^{13} \mathrm{C}$ signal over the 40 -year period. Post hoc analysis indicates that the wet site, $\mathrm{DB}$, had a higher mean tree ring $\Delta{ }^{13} \mathrm{C}$ value compared to the two drier sites of $\mathrm{BP}(p=0.03)$ and OT ( $p=0.02$; Fig. 4$)$.

\subsection{Dendroclimatology analyses}

Comparisons between ring width indices and climate data reveal that growth rates are most strongly influenced by the midgrowing season climate (May-July precipitation and maximum temperatures; July PDSI; Table S1). Since a larger proportion of annual growth occurs during the midgrowing season, higher rainfall and lower maximum temperatures during this period strongly drive annual growth rates. Similar comparisons between tree ring $\Delta^{13} \mathrm{C}$ measurements and climate data indicate that climatic conditions early in the growing season (April) are critical for causing physiological stress in these forests (Table S2).

As hypothesized, we observed a strong increase in RWI with midgrowing season precipitation. Although this positive relationship was expected for trees growing in drier conditions, we observed a similar but weaker positive relationship between RWI and precipitation even at the wet site (Tables 5, 6; Fig. 5a). We had hypothesized that, for the wettest site, radial growth would decline due to flood stress; however, no such decline was observed - even during extremely wet phases (Fig. 5a). Drought conditions and maximum temperatures during the midgrowing season resulted in decreasing RWI at the drier sites but not at the wet site, as expected (Tables 5, 6; Fig. 5b, c). Climatic variables had similar relationships with ring width indices calculated using both the ARSTAN and RCS detrending methods (Tables 5, 6). BAI 

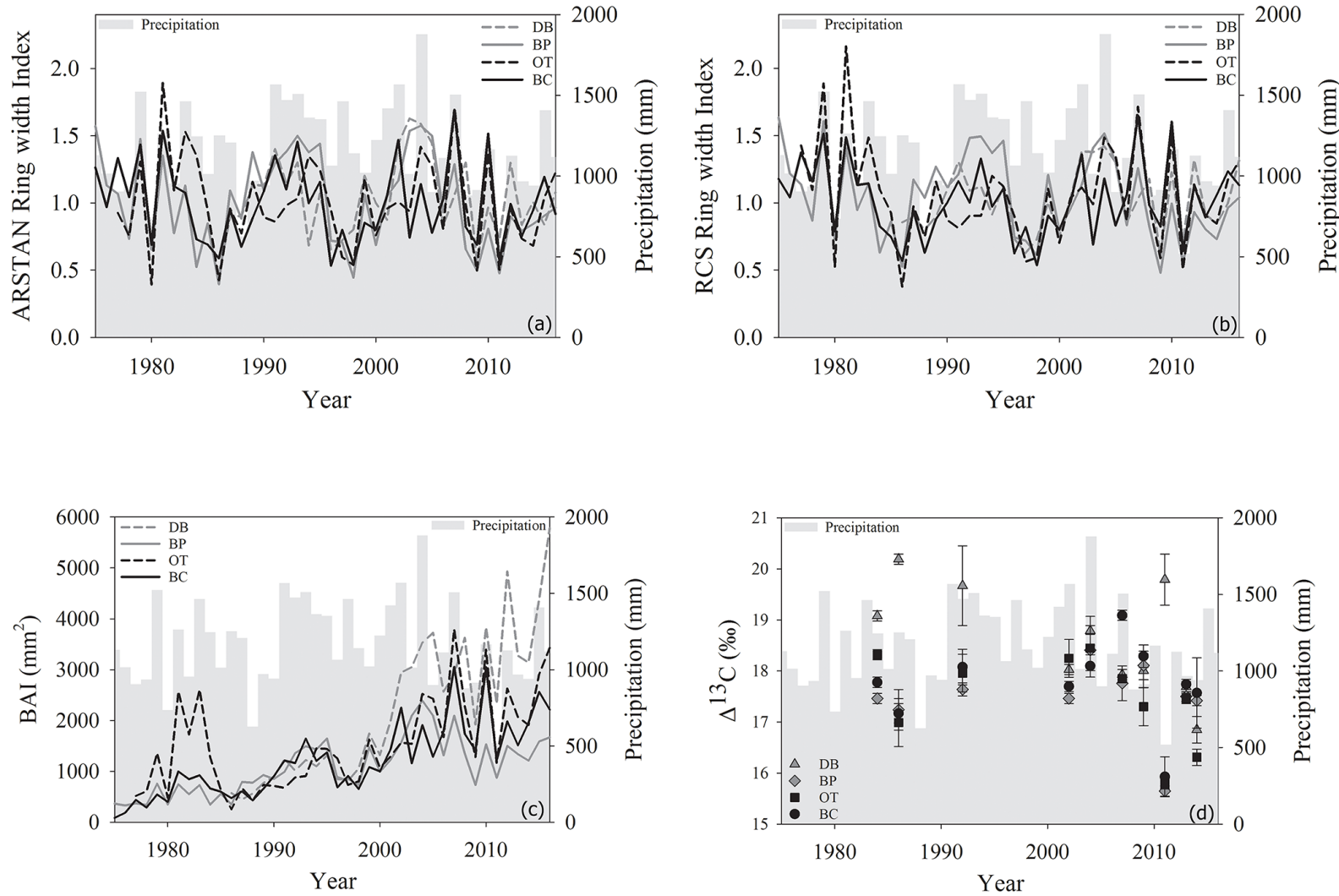

Figure 2. Temporal variation in (a) ARSTAN ring width index, (b) RCS ring width index, (c) basal area increments and (d) tree ring $\Delta^{13} \mathrm{C}$ values of Quercus nigra in the Brazos-Colorado coastal basin of Texas. Total annual precipitation is shown by the gray shading.

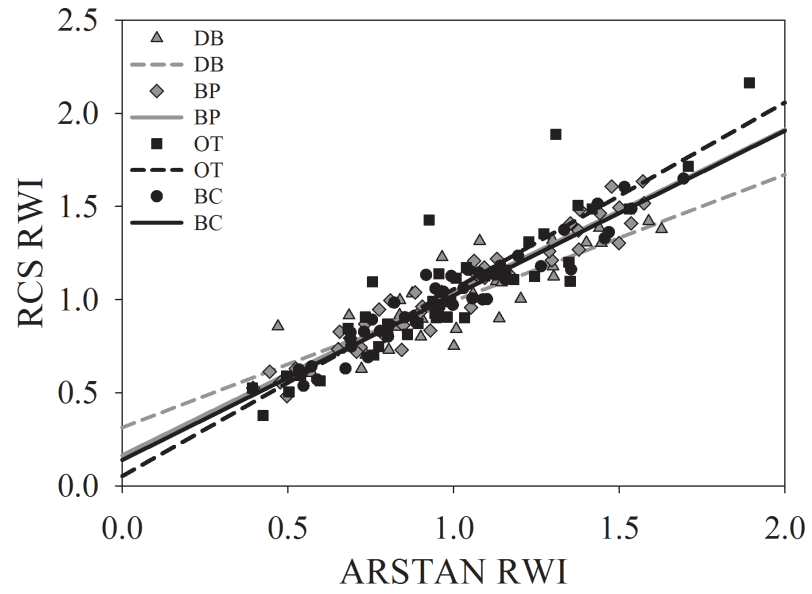

Figure 3. Relationship between site-level ring width indices calculated using RCS detrending and ARSTAN.

overall had a much weaker relationship with climatic variables. BAI at the drier sites had a weak positive relationship with precipitation, while at the wetter site, BAI was independent of precipitation (Table 7). Maximum temperature and PDSI did not affect BAI at any of the sites (Table 7).

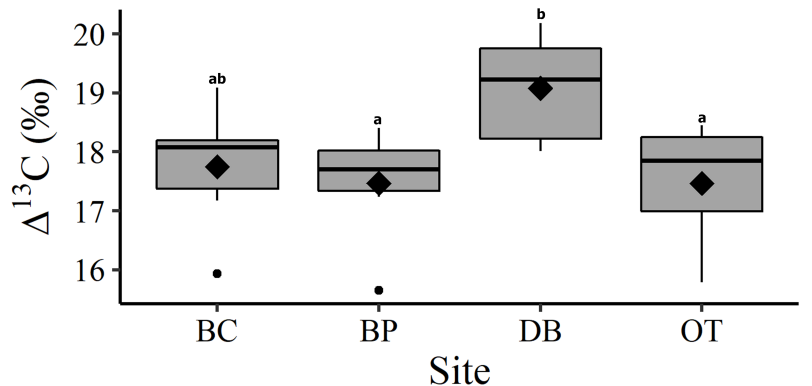

Figure 4. One-way ANOVA and Tukey post hoc analysis (denoted with letters) for mean difference in site-level tree ring $\Delta^{13} \mathrm{C}$ averaged over the 40-year period. Black diamonds indicate mean values, horizontal black lines indicate median values, black circles indicate outliers and gray boxes show values lying between the upper and lower quartiles.

In line with our second hypothesis, we observed an increase in tree ring $\Delta^{13} \mathrm{C}$ values with the increase in early growing season precipitation at the drier sites (Table 8; Fig. 6a). We had hypothesized that high precipitation at the wet site would reduce carbon isotopic discrimination as a result of physiological stress caused by possible flooding stress. However, we found no relationship between tree ring 
Table 5. Relationships between ARSTAN ring width index and midgrowing season climatic conditions $(\alpha=0.05)$. Note: Palmer drought severity index - PDSI; statistically non-significant relationships - ns.

\begin{tabular}{|c|c|c|c|c|c|c|}
\hline \multirow[t]{2}{*}{ Site } & \multicolumn{2}{|c|}{ Precipitation (May-Jul) } & \multicolumn{2}{|c|}{ Temperature (May-Jul) } & \multicolumn{2}{|c|}{ PDSI (Jul) } \\
\hline & $p$ value & $R^{2}$ & $p$ value & $R^{2}$ & $p$ value & $R^{2}$ \\
\hline DB & $<0.05$ & 0.13 & ns & - & ns & - \\
\hline $\mathrm{BP}$ & $<0.001$ & 0.39 & $<0.001$ & 0.25 & $<0.001$ & 0.49 \\
\hline OT & $<0.001$ & 0.42 & $<0.01$ & 0.17 & $<0.001$ & 0.31 \\
\hline $\mathrm{BC}$ & $<0.001$ & 0.44 & $<0.001$ & 0.27 & $<0.001$ & 0.47 \\
\hline
\end{tabular}

Table 6. Relationships between RCS ring width index and midgrowing season climatic conditions $(\alpha=0.05)$.

\begin{tabular}{|c|c|c|c|c|c|c|}
\hline \multirow[t]{2}{*}{ Site } & \multicolumn{2}{|c|}{ Precipitation (May-Jul) } & \multicolumn{2}{|c|}{ Temperature (May-Jul) } & \multicolumn{2}{|c|}{ PDSI (Jul) } \\
\hline & $p$ value & $R^{2}$ & $p$ value & $R^{2}$ & $p$ value & $R^{2}$ \\
\hline DB & $<0.05$ & 0.19 & ns & - & ns & - \\
\hline $\mathrm{BP}$ & $<0.001$ & 0.43 & $<0.01$ & 0.22 & $<0.001$ & 0.50 \\
\hline OT & $<0.001$ & 0.35 & $<0.01$ & 0.15 & $<0.001$ & 0.27 \\
\hline $\mathrm{BC}$ & $<0.001$ & 0.39 & $<0.01$ & 0.24 & $<0.001$ & 0.39 \\
\hline
\end{tabular}

$\Delta^{13} \mathrm{C}$ and precipitation at the wet site (Table 8). Higher maximum temperatures resulted in lower tree ring $\Delta^{13} \mathrm{C}$ values only at one of the drier sites (BC; Table 8; Fig. 6b). PDSI did not have any effect on tree ring $\Delta^{13} \mathrm{C}$ values from all four sites (Table 8). Also, the previous year's climate did not have any statistically significant influence on either the ring width index or tree ring $\Delta^{13} \mathrm{C}$ measurements at any of the four sites.

\subsection{Relationship between RWI and tree ring $\Delta{ }^{13} \mathrm{C}$}

The comparison between tree ring $\Delta^{13} \mathrm{C}$ values and tree ring width indices from corresponding years supports our third hypothesis only at the drier sites. ARSTAN and RCS ring width indices were correlated with $\triangle^{13} \mathrm{C}$ values only at sites OT (ARSTAN $-p<0.05 ; R^{2}=0.53$; RCS $-p<0.05$; $\left.R^{2}=0.45\right)$ and BC (ARSTAN $-p<0.05 ; R^{2}=0.58$; RCS $\left.p<0.05 ; R^{2}=0.62\right)$. Tree ring $\Delta^{13} \mathrm{C}$ values were not correlated with annual growth at the wet site DB, which indicates that trees at this site were able to minimize growth inhibition during stressful conditions compared to trees at the drier sites (Fig. 7). Tree ring $\Delta^{13} \mathrm{C}$ values were not correlated with BAI at any of the sites.

\section{Discussion}

Bottomland hardwood forests in the southeastern United States have been reduced to a small proportion of their original expanse. The hydrology of these wetland forests has been altered due to land use change and river regulation (Wear and Greis, 2002; Blann et al., 2009; Dahl, 2011), and the alteration is exacerbated by hydroclimatic anomalies such as droughts and floods (Ferrati et al., 2005; Erwin, 2008). These disturbances coupled with topographic heterogeneity cause some portions of these riverine wetland forests to be drier than others.

Contrary to our first hypothesis, similar annual radial growth of trees at the wetter site and the three drier sites during the past several decades suggests that trees at all sites have access to moisture that is sufficient to sustain annual growth. Moreover, growth of trees at the wetter site was not inhibited by excessive moisture during wet years, which may reflect an adaptation by Quercus nigra to the broad range of soil moisture conditions that occur in a floodplain forest (Gilman et al., 1994). Within the wetter site, we observed more heterogeneity in growth rates, which could be attributed to uneven waterlogging within the site. Although growth rates were correlated with rainfall across all sites, the wet site had a much weaker dependence on rainfall and showed no negative response to higher temperatures and drought severity. This suggests that wetland forests with high water tables are more independent of climatic conditions than their drier counterparts. It has been repeatedly observed across southeastern USA that, in wetter and hydrologically wellconnected parts of wetland forests, vegetation experiences lower stress during nonfavorable growing conditions (Clawson et al., 2001; Anderson et al., 2005; Gee et al., 2014; Allen et al., 2016).

Consistent with our second hypothesis, mean tree ring $\Delta^{13} \mathrm{C}$ values from the wetter site were significantly higher than those from the drier sites over a longer temporal scale, suggesting lower stomatal constraints on leaf gas exchange at the wet site compared to those at the drier sites. Also supporting our second hypothesis, reduced stomatal conductance in trees from the drier site during drought years clearly indicates prolonged stress caused by soil moisture deficit. This relationship between tree ring $\Delta^{13} \mathrm{C}$ and drought conditions 
Table 7. Relationships between basal area increment and midgrowing season climatic conditions $(\alpha=0.05)$.

\begin{tabular}{ccc|lc|l|l}
\hline Site & \multicolumn{2}{|l|}{ Precipitation (May-Jul) } & \multicolumn{2}{|l|}{ Temperature (May-Jul) } & \multicolumn{2}{|c}{ PDSI (Jul) } \\
\cline { 2 - 7 } & $p$ value & $R^{2}$ & $p$ value & $R^{2}$ & $p$ value & $R^{2}$ \\
\hline DB & ns & - & ns & - & ns & - \\
BP & $<0.05$ & 0.15 & ns & - & ns & - \\
OT & $<0.01$ & 0.18 & ns & - & ns & - \\
BC & $<0.05$ & 0.10 & ns & - & ns & - \\
\hline
\end{tabular}
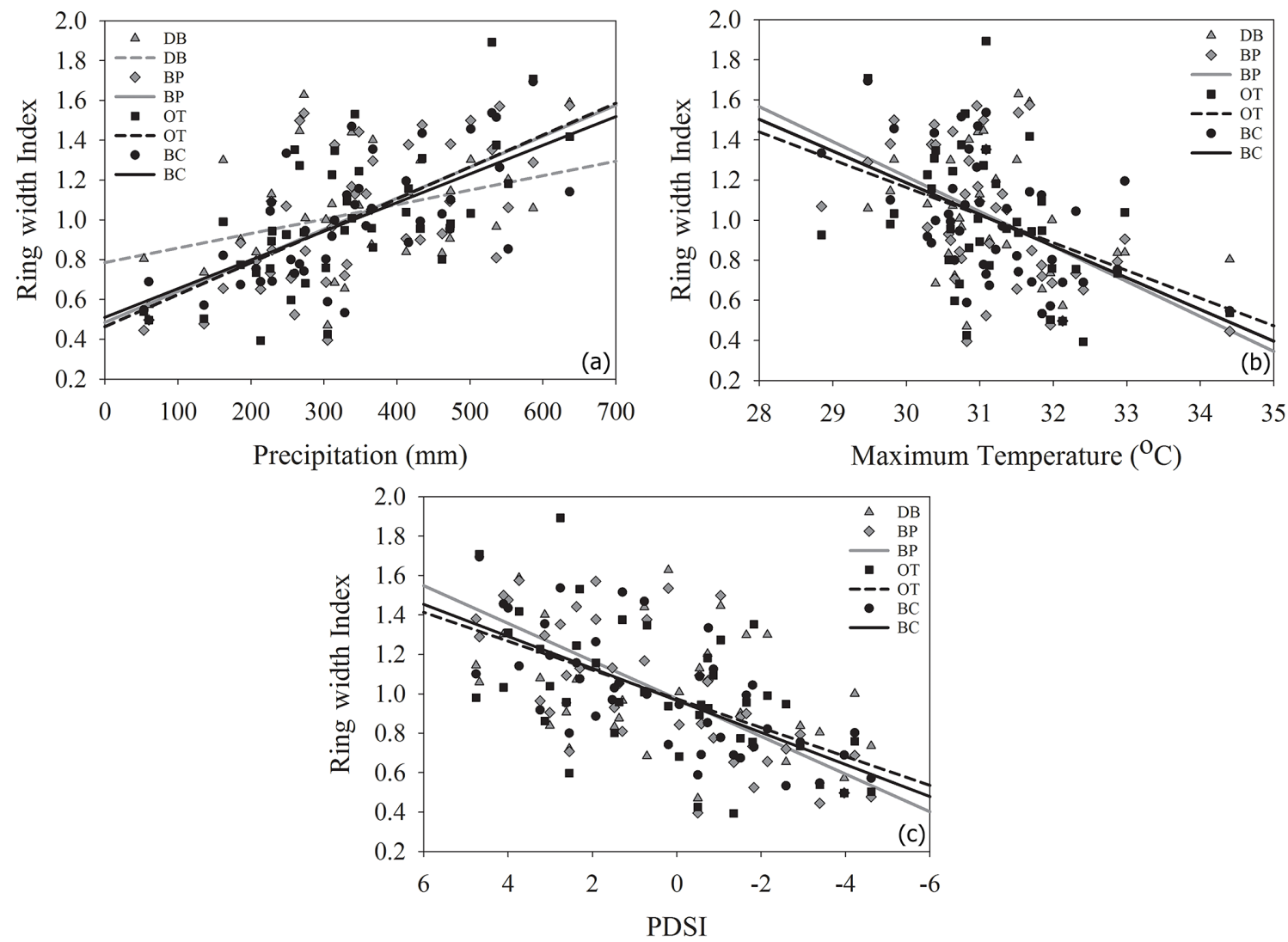

Figure 5. Relationship between ARSTAN ring width index and midgrowing season precipitation (a), temperature (b) and PDSI (c). Site DB is represented by gray triangles, BP by gray diamonds, OT by black squares and BC by black circles. Regression lines are shown only for statistically significant relationships.

Table 8. Relationships between tree ring $\Delta^{13} \mathrm{C}$ values and early growing season climatic conditions $(\alpha=0.05)$.

\begin{tabular}{ccc|ccc}
\hline Site & \multicolumn{2}{l|}{ Precipitation (Apr) } & \multicolumn{2}{|c}{ Temperature (Apr) } & PDSI \\
\cline { 2 - 6 } & $p$ value & $R^{2}$ & $p$ value & $R^{2}$ & $p$ value \\
\hline DB & $\mathrm{ns}$ & - & $\mathrm{ns}$ & - & $\mathrm{ns}$ \\
$\mathrm{BP}$ & $<0.05$ & 0.70 & $\mathrm{~ns}$ & - & $\mathrm{ns}$ \\
$\mathrm{OT}$ & $<0.05$ & 0.68 & $\mathrm{~ns}$ & - & $\mathrm{ns}$ \\
$\mathrm{BC}$ & $<0.05$ & 0.59 & $<0.001$ & 0.94 & $\mathrm{~ns}$ \\
\hline
\end{tabular}

(low precipitation and high temperatures) has been extensively observed across different ecosystems such as boreal forests (Brooks et al., 1998; Au and Tardif, 2012), wetlands (Anderson et al., 2005; Buhay et al., 2008), lowland rain forests (Schollaen et al., 2013), deserts (Lipp et al., 1996), etc. Generally, forested wetlands are not known to be drought stressed because of ample soil moisture availability. However, it is important to note that in parts of the Columbia bottomlands, depending on site-level hydrologic conditions, vegetation does experience drought stress during some years when dry climatic conditions persist over a longer period.

Our third hypothesis that tree ring $\Delta^{13} \mathrm{C}$ would have a positive relationship with radial growth holds true under dry 

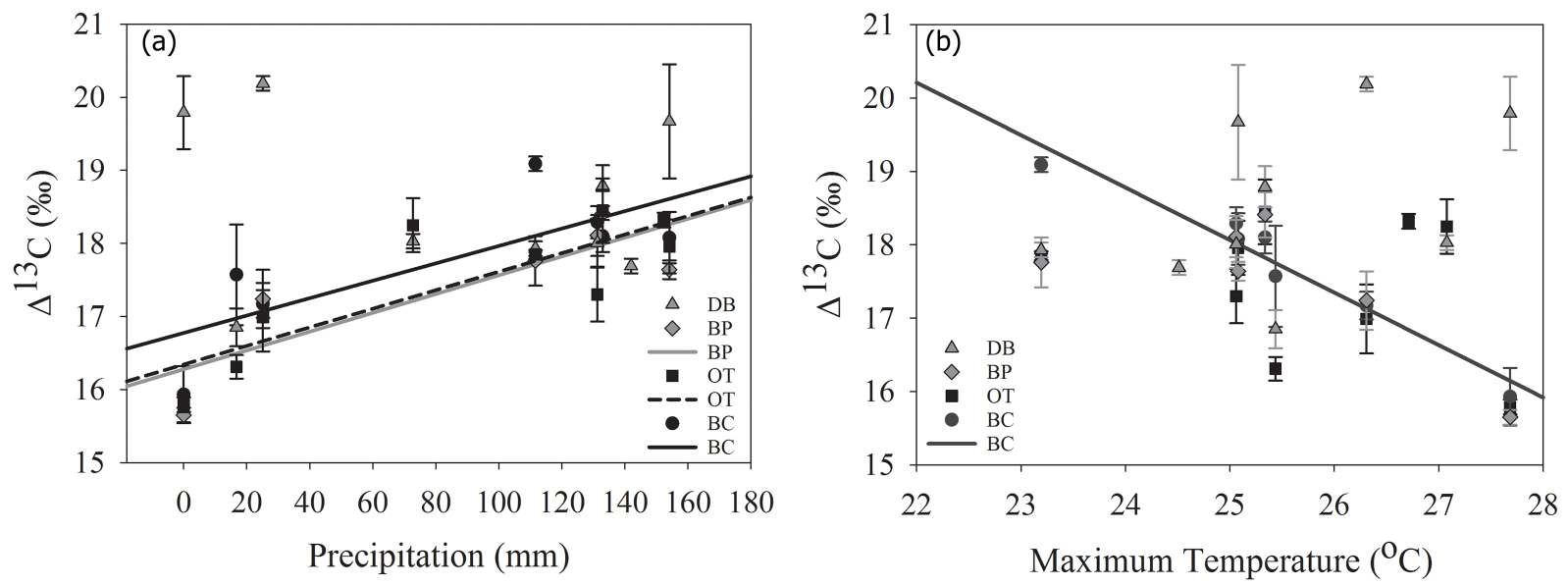

Figure 6. Relationship between tree ring $\Delta^{13} \mathrm{C}$ values and early growing season (a) precipitation and (b) temperature. Site DB is represented by gray triangles, BP by gray diamonds, OT by black squares and BC by black circles. Regression lines are shown only for statistically significant relationships.

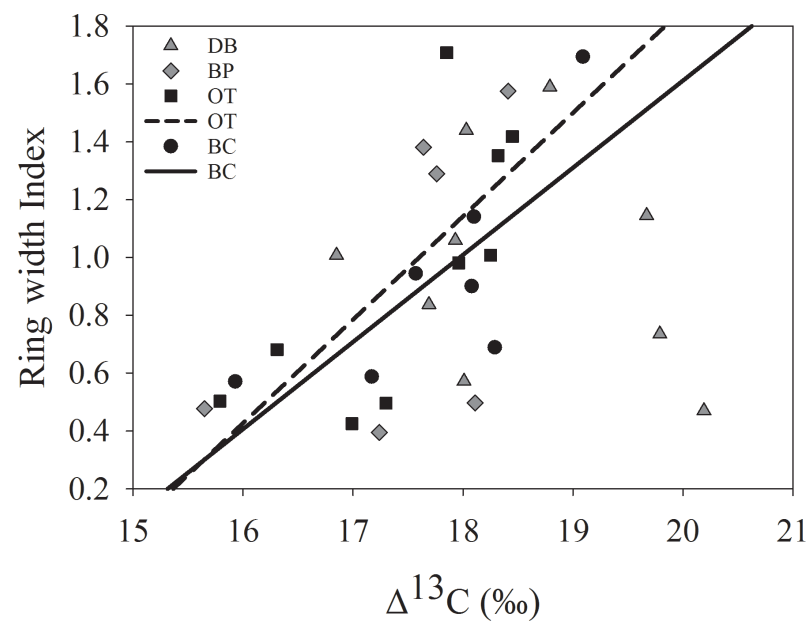

Figure 7. Relationship between ARSTAN ring width index and tree ring $\Delta^{13} \mathrm{C}$. Site $\mathrm{DB}$ is represented by gray triangles, BP by gray diamonds, OT by black squares and BC by black circles. Regression lines are shown only for statistically significant relationships.

edaphic conditions in which drought stress restricts plant growth, whereas, in trees growing in wetter soils, tree ring $\Delta^{13} \mathrm{C}$ and radial growth were largely decoupled. Similar differences in the relationship between tree ring $\Delta^{13} \mathrm{C}$ and the radial growth of the ring-porous bur oak (Quercus macrocarpa $\mathrm{M}$.) have been observed across continental gradients where tree ring $\Delta^{13} \mathrm{C}$ correlates positively with radial growth at drier sites, while the relationship is negative under wetter conditions (Voelker et al., 2014). These differences have been attributed to indicators of site aridity (vapor pressure deficit - VPD; precipitation : evapotranspiration). A similar relationship has also been observed in pond cypress trees in the southeastern Everglades, Florida, USA (Anderson et al., 2005). While we did not observe a negative relation- ship between tree ring $\Delta^{13} \mathrm{C}$ and radial growth at the wet site, no correlation between the two highlights the beneficial effect of wetter hydrological conditions on vegetation at the flooded site. Consequently, the absence of droughtrelated stress signals at the wet site is possibly due to supplemental soil moisture availability from flooding. At the drier sites, drought-related lower tree ring $\Delta^{13} \mathrm{C}$ values are correlated with slower radial growth, which indicates that moisture deficit causes physiological stress in these trees, reducing stomatal conductance and eventually inhibiting growth. Additionally, tree ring $\Delta^{13} \mathrm{C}$ and radial growth at the wet site were uncorrelated, especially during years when growing season precipitation was more erratic (i.e., a dry spring followed by a wet summer and vice versa). The drought effect of drier hydroclimatic conditions is ephemeral and less intense at the wet site due to the slower depletion of soil water reserves. Therefore, seasonal dry spells slightly reduce tree ring $\Delta^{13} \mathrm{C}$ but do not always result in growth inhibition in wetter parts of this landscape due to sufficient moisture availability. We had expected to observe lower tree ring $\Delta^{13} \mathrm{C}$ values during extremely wet growing seasons due to flooding stress, but the absence of these signals indicates adaptation to excessive wetness. It has been suggested that wetland species that experience frequent flooding develop adaptive traits that enable the rapid reopening of stomata with the recession of flood waters as oxygen availability in the root zone increases (Crawford, 1982; Kozlowski and Pallardy, 1984; Kozlowski, 2002). Consistent with this, our observations signify that trees growing in drier conditions do have a more distinct tree ring $\Delta^{13} \mathrm{C}$-growth relationship compared to those growing in wet conditions.

We found that midgrowing season precipitation (from May to July) is most critical for growth in this landscape. Similarly, high temperatures during the same period were associated with suppressed growth. Therefore, adequate precipita- 
tion and moderate temperatures during this period are important controls over tree growth. However, due to the changing climatic conditions and altered hydrology of this region, a change in the seasonal moisture availability during this period can result in reduced productivity. Unlike the trees growing in drier conditions, the ones at the wet site are not affected by temperature and drought severity throughout the growing season, possibly because of residual soil moisture availability despite evaporation caused by higher temperatures. It is important to consider seasonal variation in precipitation because flood conditions in the dormant winter season do not necessarily help to sustain growth throughout the summer in drier sites, especially if summers have below-normal precipitation. On the other hand, trees at the wet site may benefit from access to soil moisture reserves from waterlogging caused by winter precipitation.

While the growth-climate relationship is more amplified during midgrowing season, tree ring $\Delta^{13} \mathrm{C}$ is more prominently dependent on early growing season precipitation. Lack of precipitation early in the growing season (April) results in substantial physiological stress caused by reduced stomatal conductance in trees at the drier sites. This is an indication that although dry conditions early in the growing season cause stress in trees, most growth is attained during the midgrowing season. Therefore, trees can recover from the stress and attain normal growth rates if adequate precipitation occurs during the midgrowing season. The prominent dependence of physiological stress on spring precipitation could be the result of more energy and resource allocation during leaf out. However, this holds true only under dry edaphic conditions. Such seasonal variations have been observed across different biomes and have been attributed to the formation of wood using previous or current growing season assimilates (Schollaen et al., 2013). It is apparent that, if wood at the very beginning of the growing season is formed using assimilates from the previous growing season, earlywood tree ring $\Delta^{13} \mathrm{C}$ does not have a correlation with early growing season precipitation from the current year (Helle and Schleser, 2004; Porter et al., 2009; Schollaen et al., 2013). In our study, tree ring $\Delta^{13} \mathrm{C}$ is well correlated with early growing season precipitation from the current growing season. Although this indicates that the majority of annual wood is formed using assimilates from the current growing season, it needs to be noted that earlywood portions of ring-porous oaks like those of Q. nigra have lower wood density (Gasson, 1987; Lei et al., 1996; Rao, 1997). Therefore, by using entire annual ring composites, the relatively small signal from the previous year could be present but not distinctly detected. Hence, comparing our ring width indices and tree ring $\Delta^{13} \mathrm{C}$ values with previous years' climate yields no correlation $(p>0.05)$, indicating its relatively weak effect.

Climate models have predicted a significant decrease in growing season precipitation and an increase in temperature throughout Texas (Jiang and Yang, 2012) and especially in the Brazos River basin (Awal et al., 2016) where our study area is located. This region is located at the extreme southwestern edge of the bottomland hardwood forest type (Bray, 1906; Putnam et al., 1960), which is also the southwestern edge of the distribution of $Q$. nigra and many other wetland tree species. Edges of distribution ranges usually experience environmental conditions that are less favorable (drier and warmer) to the species compared to the range core (Rehm et al., 2015), which makes them more resilient and better adapted to surviving stressful conditions relative to core populations (Gutschick and Hormoz, 2003). Therefore, as climate changes, these native wetland tree populations will play key roles in helping the species maintain their geographic distributions.

\section{Conclusions}

This study provides insights on hydroclimatic conditions that can provide suitable conditions for better wetland forest productivity and health. Columbia bottomlands support a large diversity of plants, mammals, birds, reptiles and insects. The knowledge of optimum growing conditions for the vegetation in this region is critical for the survival and conservation of the biodiversity that is dependent on this ecosystem. We provide evidence that hydrologically wetter portions of this landscape experience less stress and, subsequently, lower growth inhibition in response to hydroclimatic changes compared to drier areas. Trees in drier areas grew more slowly during dry and warm periods and were more sensitive to seasonal physiological stress. We observed variation in growth and stress responses to climatic conditions during different phases of the growing season. Our findings suggest that hydroclimatic changes to this ecosystem that alter the timing and frequency of wet conditions can negatively impact forest health. This study also provides the first tree ring records from the Columbia bottomlands, which can act as a baseline for future ecological research in the region.

Data availability. All data resulting from this study are available from the authors upon request (ajinkyagd@tamu.edu).

Supplement. The supplement related to this article is available online at: https://doi.org/10.5194/bg-17-5639-2020-supplement.

Author contributions. AGD conceptualized the study, developed the methodology, collected field samples, conducted formal analysis, including laboratory and statistical analysis, and wrote the original draft. TWB contributed to the conceptualization of the study, provided laboratory equipment and materials for stable carbon isotope analysis and edited and reviewed the original draft. AH provided laboratory protocols for cellulose extraction, provided laboratory equipment and materials for stable carbon isotope analysis and analyzed the samples for isotopic composition. CWL contributed to 
the conceptualization of the study, provided all the required equipment for dendrochronology and edited and reviewed the original draft. GWM was the investigator and supervisor of the study, played a major role in conceptualization of the study, contributed to developing the methodology and statistical analyses, acquired funds for the study and edited and reviewed the original draft.

Competing interests. The authors declare that they have no conflict of interest.

Acknowledgements. The authors are thankful to Parveen Chhetri and the entire Texas Water Observatory team for supporting this study. We would also like to thank Jennifer Sanchez and Curtis Jones from the U.S. Fish and Wildlife Service, San Bernard National Wildlife Refuge, for providing access to the study sites (permit no. 17-0005).

Financial support. This study has been funded by the Texas A\&M University Research Development Fund, by the USDA/NIFA Hatch project (1020427) and by the Sid Kyle Endowed Chair in the Department of Ecology and Conservation Biology at Texas A\&M University.

Review statement. This paper was edited by Christopher Still and reviewed by Steve Voelker and two anonymous referees.

\section{References}

Allen, S. T., Krauss, K. W., Cochran, J. W., King, S. L., and Keim, R. F.: Wetland tree transpiration modified by riverfloodplain connectivity, J. Geophys. Res. G, 121, 753-766, https://doi.org/10.1002/2015JG003208, 2016.

Anderson, W. T., Sternberg, L. S. L., Pinzon, M. C., GannTroxler, T., Childers, D. L., and Duever, M.: Carbon isotopic composition of cypress trees from South Florida and changing hydrologic conditions, Dendrochronologia, 23, 1-10, https://doi.org/10.1016/j.dendro.2005.07.006, 2005.

Astrade, L. and Bégin, Y.: Tree-ring response of Рориlus tremula L. and Quercus robur L. to recent spring floods of the Saône River, France, Écoscience, 4, 232-239, https://doi.org/10.1080/11956860.1997.11682400, 1997.

$\mathrm{Au}, \mathrm{R}$. and Tardif, J. C.: Drought signals inferred from ringwidth and stable carbon isotope chronologies from Thuja occidentalis trees growing at their northwestern distribution limit, central Canada, Can. J. Forest Res., 42, 517-531, https://doi.org/10.1139/x2012-012, 2012.

Awal, Bayabil, K. H., and Fares, A.: Analysis of potential future climate and climate extremes in the Brazos Headwaters Basin, Texas, Water, 8, 603-620, https://doi.org/10.3390/w8120603, 2016.

Babst, F., Poulter, B., Trouet, V., Tan, K., Neuwirth, B., Wilson, R., Carrer, M., Grabner, M., Tegel, W., Levanic, T., Panayotov, M., Urbinati, C., Bouriaud, O., Ciais, P., and Frank, D.: Site- and species-specific responses of forest growth to climate across the European continent, Glob. Ecol. Biogeogr., 22, 706-717, https://doi.org/10.1111/geb.12023, 2013.

Ballesteros-Canovas, J., Stoffel, M., St. George, S., and Katie, H.: A review of flood records from tree rings, Prog. Phys. Geogr., 39, 1-23, https://doi.org/10.1177/0309133315608758, 2015.

Barrow, W. C. and Renne, I.: Interactions between migrant landbirds and an invasive exotic plant: the Chinese tallow tree, Flyway, 8, 2001.

Barrow, W. C., Johnson Randall, L. A., Woodrey, M. S., Cox, J., Ruelas Inzunza, E., Riley, C. M., Hamilton, R. B., and Eberly, C.: Coastal forests of the Gulf of Mexico: a description and some thoughts on their conservation, General Technical Report PSWGTR-191, U.S. Department of Agriculture, Forest Service, Washington, DC, 450-464, 2005.

Biondi, F.: Comparing tree-ring chronologies and repeated timber inventories as forest monitoring tools, Ecol. Appl., 9, 216-227, https://doi.org/10.1890/10510761(1999)009[0216:Ctrcar]2.0.Co;2, 1999.

Biondi, F. and Qeadan, F.: A theory-driven approach to treering standardization: Defining the biological trend from expected basal area increment, Tree-Ring Res., 64, 81-96, https://doi.org/10.3959/2008-6.1, 2008.

Blann, K., Anderson, J., Sands, G., and Vondracek, B.: Effects of agricultural drainage on aquatic ecosystems: A review, Crit. Rev. Env. Sci. Tech., 39, 909-1001, https://doi.org/10.1080/10643380801977966, 2009.

Bray, W. L.: Distribution and adaptation of the vegetation of Texas, Bulletin 82, no. 10, University of Texas, Austin, 1-14, 1906.

Briffa, K. R., Jones, P. D., Bartholin, T. S., Eckstein, D., Schweingruber, F. H., Karlén, W., Zetterberg, P., and Eronen, M.: Fennoscandian summers from ad 500: temperature changes on short and long timescales, Clim. Dynam., 7, 111-119, https://doi.org/10.1007/BF00211153, 1992.

Briffa, K. R. and Melvin, T. M.: A closer look at Regional Curve Standardization of tree-ring records: Justification of the need, a warning of some pitfalls, and suggested improvements in its application, in: Dendroclimatology: Progress and Prospects, edited by: Hughes, M. K., Swetnam, T. W., and Diaz, H. F., Springer Netherlands, Dordrecht, 113-145, 2011.

Brooks, J. R., Flanagan, L. B., and Ehleringer, J. R.: Responses of boreal conifers to climate fluctuations: indications from tree-ring widths and carbon isotope analyses, Can. J. Forest Res., 28, 524533, https://doi.org/10.1139/x98-018, 1998.

Buhay, W. M., Timsic, S., Blair, D., Reynolds, J., Jarvis, S., Petrash, D., Rempel, M., and Bailey, D.: Riparian influences on carbon isotopic composition of tree rings in the Slave River Delta, Northwest Territories, Canada, Chem. Geol., 252, 9-20, https://doi.org/10.1016/j.chemgeo.2008.01.012, 2008.

Bunn, A. G.: A dendrochronology program library in $\mathrm{R}$ (dplR), Dendrochronologia, 26, 115-124, https://doi.org/10.1016/j.dendro.2008.01.002, 2008.

Charney, N. D., Babst, F., Poulter, B., Record, S., Trouet, V. M., Frank, D., Enquist, B. J., and Evans, M. E. K.: Observed forest sensitivity to climate implies large changes in 21 st century North American forest growth, Ecol. Lett., 19, 1119-1128, https://doi.org/10.1111/ele.12650, 2016.

Clawson, R. G., Lockaby, B. G., and Rummer, B.: Changes in production and nutrient cycling across a wetness gra- 
dient within a floodplain forest, Ecosystems, 4, 126-138, https://doi.org/10.1007/s100210000063, 2001.

Cook, E. R. and Holmes, R. L.: Program ARSTAN users manual, Laboratory of Tree-Ring Research, University of Arizona, Tucson, 15, 50-65, 1984.

Coplen, T. B.: Reporting of stable hydrogen, carbon, and oxygen isotopic abundances, Geothermics, 24, 707-712, https://doi.org/10.1016/0375-6505(95)00024-0, 1995.

Crawford, R. M. M.: Physiological responses to flooding, in: Physiological Plant Ecology II, Encyclopedia of Plant Physiology (New Series), edited by: Lange, O. L., Nobel, P. S., Osmond, C. B., and Ziegler, H. E., Springer, Berlin, Heidelberg, 453-477, 1982.

Cullen, L. and Macfarlane, C.: Comparison of cellulose extraction methods for analysis of stable isotope ratios of carbon and oxygen in plant material, Tree Physiol., 25, 563-569, https://doi.org/10.1093/treephys/25.5.563, 2005.

Dahl, T. E.: Status and trends of wetlands in the conterminous United States 2004 to 2009, U.S. Fish and Wildlife Service, available at: https://www.fws.gov/wetlands/Documents/ (last access: 18 March 2020), 2011.

Davies, F. S. and Flore, J. A.: Flooding, gas exchange and hydraulic root conductivity of highbush blueberry, Physiol. Plantarum, 67, 545-551, https://doi.org/10.1111/j.13993054.1986.tb05053.x, 1986.

Ehleringer, J. R., Hall, A. E., and Farquhar, G. D.: Stable isotopes and plant carbon/water relations, Academic Press, San Diego, 555 pp., 1993.

Erlandsson, S.: Dendrochronological studies, Geochronology Institute Report 23, University of Upsala, 1-119, 1936.

Erwin, K. L.: Wetlands and global climate change: the role of wetland restoration in a changing world, Wetl. Ecol. Manag., 17, 71-84, https://doi.org/10.1007/s11273-008-9119-1, 2008.

Ewe, S. M. and Sternberg, D. L.: Seasonal water-use by the invasive exotic, Schinus terebinthifolius, in native and disturbed communities, Oecologia, 133, 441-448, https://doi.org/10.1007/s00442002-1047-9, 2002.

Ewe, S. M. L. and Sternberg, L.: Seasonal gas exchange characteristics of Schinus terebinthifolius in a native and disturbed upland community in Everglades National Park, Florida, Forest Ecol. Manage., 179, 27-36, https://doi.org/10.1016/S03781127(02)00531-5, 2003.

Fang, K., Gou, X., Chen, F., Cook, E., Li, J., Buckley, B., and D'Arrigo, R.: Large-scale precipitation variability over Northwest China inferred from tree rings, J. Clim., 24, 3457-3468, https://doi.org/10.1175/2011JCLI3911.1, 2011.

Farquhar, G.: On the nature of carbon isotope discrimination in $\mathrm{C}_{4}$ species, Funct. Plant Biol., 10, 205-226, https://doi.org/10.1071/PP9830205, 1983.

Farquhar, G. D., Hubick, K. T., Condon, A. G., and Richards, R. A.: Carbon isotope fractionation and plant water-use efficiency, in: Stable Isotopes in Ecological Research, edited by: Rundel, P. W., Ehleringer, J. R., and Nagy, K. A., Ecological Studies (Analysis and Synthesis), Springer, New York, NY, 21-40, 1989.

Ferrati, R., Ana Canziani, G., and Ruiz Moreno, D.: Esteros del Ibera: hydrometeorological and hydrological characterization, Ecol. Model., 186, 3-15, https://doi.org/10.1016/j.ecolmodel.2005.01.021, 2005.
Fisher, R. E., France, J. L., Lowry, D., Lanoisellé, M., Brownlow, R., Pyle, J. A., Cain, M., Warwick, N., Skiba, U. M., Drewer, J., Dinsmore, K. J., Leeson, S. R., Bauguitte, S. J.-B., Wellpott, A., O'Shea, S. J., Allen, G., Gallagher, M. W., Pitt, J., Percival, C. J., Bower, K., George, C., Hayman, G. D., Aalto, T., Lohila, A., Aurela, M., Laurila, T., Crill, P. M., McCalley, C. K., and Nisbet, E. G.: Measurement of the ${ }^{13} \mathrm{C}$ isotopic signature of methane emissions from northern European wetlands, Global Biogeochem. Cy., 31, 605-623, https://doi.org/10.1002/2016gb005504, 2017.

Gao, S., Liu, R., Zhou, T., Fang, W., Yi, C., Lu, R., Zhao, X., and Luo, H.: Dynamic responses of tree-ring growth to multiple dimensions of drought, Glob. Change Biol., 24, 5380-5390, https://doi.org/10.1111/gcb.14367, 2018.

Gasson, P.: Some implications of anatomical variations in the wood of Pedunculate Oak (Quercus Robur L.), including comparisons with Common Beech (Fagus Sylvatica L.), 8, 149-166, https://doi.org/10.1163/22941932-90001042, 1987.

Gee, H. K. W., King, S. L., and Keim, R. F.: Tree growth and recruitment in a leveed floodplain forest in the Mississippi River Alluvial Valley, USA, Forest Ecol. Manag., 334, 85-95, https://doi.org/10.1016/j.foreco.2014.08.024, 2014.

Gessler, A., Brandes, E., Buchmann, N., Helle, G., Rennenberg, H., and Barnard Romain, L.: Tracing carbon and oxygen isotope signals from newly assimilated sugars in the leaves to the tree-ring archive, Plant Cell Environ., 32, 780-795, https://doi.org/10.1111/j.1365-3040.2009.01957.x, 2009.

Gessler, A., Ferrio, J. P., Hommel, R., Treydte, K., Werner, R. A., and Monson, R. K.: Stable isotopes in tree rings: towards a mechanistic understanding of isotope fractionation and mixing processes from the leaves to the wood, Tree Physiol., 34, 796-818, https://doi.org/10.1093/treephys/tpu040, 2014.

Gilman, E. F., Watson, D. G., Klein, R. W., Koeser, A. K., Hilbert, D. R., and McLean, D. C.: Quercus nigra: Water Oak, Environmental Horticulture Department, Florida Cooperative Extension Service, Institute of Food and Agricultural Sciences, University of Florida, available at: https://edis.ifas.ufl.edu/pdffiles/ ST/ST55300.pdf (last access: 24 March 2020), 1994.

Graven, H., Allison, C. E., Etheridge, D. M., Hammer, S., Keeling, R. F., Levin, I., Meijer, H. A. J., Rubino, M., Tans, P. P., Trudinger, C. M., Vaughn, B. H., and White, J. W. C.: Compiled records of carbon isotopes in atmospheric $\mathrm{CO}_{2}$ for historical simulations in CMIP6, Geosci. Model Dev., 10, 4405-4417, https://doi.org/10.5194/gmd-10-4405-2017, 2017.

Green, J. W.: Wood cellulose, in: Methods in Carbohydrate Chemistry, edited by: Whistler, R. L., Academic Press, New York, 9$21,1963$.

Griffith, G. E., Bryce, S. A., Omernik, J. M., Comstock, J. A., Rogers, A. C., Harrison, B., Hatch, S. L., and Bezanson, D.: Ecoregions of Texas (map poster), U.S. Geological Survey, Reston, VA, Scale $1: 2,500,000,2004$.

Grissino-Mayer, H.: Evaluating crossdating accuracy: a manual and tutorial for the computer program COFECHA, Tree-Ring Res., 57, 205-221, 2001.

Guerra, K. A.: Ecohydrological analysis in a forest ecosystem of seasonal variations in the moisture content of clay-rich soil, Master of Science Dissertation, Department of Geology \& Geophysics, Texas A\&M University, College Station, TX, 2020.

Gutschick, V. P. and Hormoz, B.: Extreme events as shaping physiology, ecology, and evolution of plants: toward a unified defi- 
nition and evaluation of their consequences, New Phytol., 160, 21-42, https://doi.org/10.1046/j.1469-8137.2003.00866.x, 2003.

Helle, G. and Schleser, G. H.: Beyond $\mathrm{CO}_{2}$-fixation by Rubisco an interpretation of ${ }^{13} \mathrm{C} /{ }^{12} \mathrm{C}$ variations in tree rings from novel intra-seasonal studies on broad-leaf trees, Plant Cell Environ., 27, 367-380, https://doi.org/10.1111/j.0016-8025.2003.01159.x, 2004.

Hoerling, M., Kumar, A., Dole, R., Nielsen-Gammon, J. W., Eischeid, J., Perlwitz, J., Quan, X.-W., Zhang, T., Pegion, P., and Chen, M.: Anatomy of an extreme event, J. Clim., 26, 28112832, https://doi.org/10.1175/jcli-d-12-00270.1, 2013.

Holmes, R. L.: Computer-assisted quality control in tree-ring dating and measurement, Tree-Ring Bull., 43, 51-67, http://hdl.handle. net/10150/261223, 1983.

Houston Wilderness: Houston wilderness, Houston atlas of biodiversity, Columbia Bottomlands map, Texas A\&M Press, available http://houstonwilderness.org/colombia-bottomlands (last access: 10 February 2020), 2007.

Jackson, M. B. and Drew, M. C.: Effects of flooding on growth and metabolism of herbaceous plants, in: Flooding and Plant Growth, edited by: Kozlowski, T. T., Academic Press, San Diego, 47-128, 1984.

Jiang, X. and Yang, Z. L.: Projected changes of temperature and precipitation in Texas from downscaled global climate models, Clim. Res., 53, 229-244, https://doi.org/10.3354/cr01093, 2012.

Kearns, T., Wang, G., Bao, Y., Jiang, J., and Lee, D.: Current land subsidence and groundwater level changes in the Houston Metropolitan Area (2005-2012), J. Surv. Eng., 141, 05015002, https://doi.org/10.1061/(ASCE)SU.1943-5428.0000147, 2015.

Keeling, R. F. and Keeling, C. D.: Atmospheric In Situ $\mathrm{CO}_{2}$ Data - La Jolla Pier, California and Mauna Loa Observatory, Hawaii, in: Scripps $\mathrm{CO}_{2}$ Program Data, UC San Diego Library Digital Collections, https://doi.org/10.6075/J0QJ7F7N, 2017.

Koppen, W.: Versuch einer Klassifikation der Klimate, vorzugsweise nach ihren Beziehungen zur Pflanzenwelt, Geogr. Z., 6, 593-611, 1900.

Kozlowski, T.: Physiological-ecological impacts of flooding on riparian forest ecosystems, Wetlands, 22, 550-561, https://doi.org/10.1672/02775212(2002)022[0550:PEIOFO]2.0.CO;2, 2002.

Kozlowski, T. T. and Pallardy, S. G.: Effect of flooding on water, carbohydrate, and mineral relations, in: Flooding and Plant Growth, edited by: Kozlowski, T. T., Academic Press, San Diego, 165-193, 1984.

Kozlowski, T. T.: Responses of woody plants to flooding and salinity, Tree Physiol., 17, 490-490, https://doi.org/10.1093/treephys/17.7.490, 1997.

Leavitt, S., Wright, W., and Long, A.: Spatial expression of ENSO, drought, and summer monsoon in seasonal $\delta^{13} \mathrm{C}$ of ponderosa pine tree rings in southern Arizona and New Mexico, J. Geophys. Res.-Atmos., 107, 1-10, https://doi.org/10.1029/2001JD001312, 2002.

Leavitt, S. W. and Danzer, S. R.: Method for batch processing small wood samples to holocellulose for stable-carbon isotope analysis, Anal. Chem., 65, 87-89, https://doi.org/10.1021/ac00049a017, 1993.

LeBlanc, D. C. and Stahle, D. W.: Radial growth responses of four oak species to climate in eastern and central North America, Can.
J. Forest Res., 45, 793-804, https://doi.org/10.1139/cjfr-20150020, 2015.

Lei, H., Milota, M. R., and Gartner, B. L.: Between- and within-tree variation in the anatomy and specific gravity of wood in oregon white oak (Quercus garryana Dougl.), 1AWA J., 17, 445-461, https://doi.org/10.1163/22941932-90000642, 1996.

Lipp, J., Trimborn, P., Edwards, T., Waisel, Y., and Yakir, D.: Climatic effects on the $\delta^{18} \mathrm{O}$ and $\delta^{13} \mathrm{C}$ of cellulose in the desert tree Tamarix jordanis, Geochim. Cosmochim. Ac., 60, 3305-3309, https://doi.org/10.1016/0016-7037(96)00166-4, 1996.

McCarroll, D. and Loader, N. J.: Stable isotopes in tree rings, Quaternary Sci. Rev., 23, 771-801, https://doi.org/10.1016/j.quascirev.2003.06.017, 2004.

Meko, M. D. and Therrell, M. D.: A record of flooding on the White River, Arkansas derived from tree-ring anatomical variability and vessel width, Phys. Geogr., 41, 83-98, https://doi.org/10.1080/02723646.2019.1677411, 2020.

Miao, S., Zou, C., and Breshears, D.: Vegetation responses to extreme hydrological events: Sequence matters, Am. Natural., 173, 113-118, https://doi.org/10.1086/593307, 2009.

Mikac, S., Žmegač, A., Trlin, D., Paulić, V., Oršanić, M., and Anić, I.: Drought-induced shift in tree response to climate in floodplain forests of Southeastern Europe, Sci. Rep., 8, 16495, https://doi.org/10.1038/s41598-018-34875-w, 2018.

Moore, G., Edgar, C. B., Vogel, J., Washington-Allen, R., March, R., and Zehnder, R.: Tree mortality from an exceptional drought spanning mesic to semiarid ecoregions, Ecol. Appl., 26, 602611, https://doi.org/10.1890/15-0330.1, 2015.

National Inventory of Dams: U.S. Army Corps of Engineers, available at: https://nid.sec.usace.army.mil/ords/f?p=105:113: 891673838449::NO:::, last access: 26 March 2020.

NOAA: National Centers for Environmental Information, National Oceanic and Atmospheric Administration, United States Department of Commerce, available at: https://www.ncdc.noaa.gov/ data-access/land-based-station-data (last access: 18 July 2018), 2018a.

NOAA: National Centers for Environmental Information, National Environmental Satellite, Data, and Information Service, United States Department of Commerce, available at: https: //www7.ncdc.noaa.gov/CDO/CDODivisionalSelect.jsp (last access: 19 June 2020), 2018 b.

NRCS: Soil Survey Staff, Natural Resources Conservation Service, United States Department of Agriculture, Web Soil Survey, available at: https://websoilsurvey.sc.egov.usda.gov/ (last access: 9 February 2020), 2020.

Oren, R., Sperry, J. S., Ewers, B. E., Pataki, D. E., Phillips, N., and Megonigal, J. P.: Sensitivity of mean canopy stomatal conductance to vapor pressure deficit in a flooded Taxodium distichum L. forest: hydraulic and non-hydraulic effects, Oecologia, 126, 21-29, https://doi.org/10.1007/s004420000497, 2001.

Porter, T. J., Pisaric, M. F. J., Kokelj, S. V., and Edwards, T. W. D.: Climatic signals in $\delta^{13} \mathrm{C}$ and $\delta^{18} \mathrm{O}$ of tree-rings from white spruce in the Mackenzie Delta Region, Northern Canada, Arct. Antarct. Alpine Res., 41, 497-505, https://doi.org/10.1657/19384246-41.4.497, 2009.

Putnam, J. A., Furnival, G. M., and McKnight, J. S.: Management and Inventory of Southern Hardwoods, Agriculture Handbook 181, U.S. Department of Agriculture, Forest Service, Washington, DC, 1-108, 1960. 
R Core Team: R: A language and environment for statistical computing. R Foundation for Statistical Computing, Vienna, Austria, ISBN 3-900051-07-0, available at: http://www.R-project. org/ (last access: 10 February 2020), 2012.

Rao, R. V.: Latewood density in relation to wood fibre diameter, wall thickness, and fibre and vessel percentages in Quercus Robur L, 18, 127-138, https://doi.org/10.1163/2294193290001474, 1997.

Rehm, Paulo, O., James, S., and J., F. K.: Losing your edge: climate change and the conservation value of rangeedge populations, Ecology and Evolution, 5, 4315-4326, https://doi.org/10.1002/ece3.1645, 2015.

Robertson, I., Switsur, V. R., Carter, A. H. C., Barker, A. C., Waterhouse, J. S., Briffa, K. R., and Jones, P. D.: Signal strength and climate relationships in ${ }^{13} \mathrm{C} /{ }^{12} \mathrm{C}$ ratios of tree ring cellulose from oak in east England, J. Geophys. Res-Atmos., 102, 1950719516, https://doi.org/10.1029/97JD01226, 1997.

Rosen, D., Steven, D., and Lange, M.: Conservation strategies and vegetation characterization in the Columbia Bottomlands, an under-recognized southern floodplain forest formation, Nat. Area. J., 28, 74-82, https://doi.org/10.3375/08858608(2008)28[74:CSAVCI]2.0.CO;2, 2008.

Saurer, M., Siegenthaler, U., and Schweingruber, F.: The climate-carbon isotope relationship in tree rings and the significance of site conditions, Tellus B, 47, 320-330, https://doi.org/10.3402/tellusb.v47i3.16051, 1995.

Schmidt, D. H. and Garland, K. A.: Bone dry in Texas: Resilience to drought on the Upper Texas Gulf Coast, J. Plan. Lit., 27, 434445, https://doi.org/10.1177/0885412212454013, 2012.

Schollaen, K., Heinrich, I., Neuwirth, B., Krusic, P. J., D’Arrigo, R. D., Karyanto, O., and Helle, G.: Multiple tree-ring chronologies (ring width, $\delta^{13} \mathrm{C}$ and $\delta^{18} \mathrm{O}$ ) reveal dry and rainy season signals of rainfall in Indonesia, Quaternary Sci. Rev., 73, 170-181, https://doi.org/10.1016/j.quascirev.2013.05.018, 2013.

Seager, Ting, M., Held, I., Kushnir, Y., Lu, J., Vecchi, G., Huang, H.-P., Harnik, N., Leetmaa, A., Lau, N.-C., Li, C., Velez, J., and Naik, N.: Model projections of an imminent transition to a more arid climate in southwestern North America, Science, 316, 1181, https://doi.org/10.1126/science.1139601, 2007.

Sebastian, A., Gori, A., Blessing, R. B., van der Wiel, K., and Bass, B.: Disentangling the impacts of human and environmental change on catchment response during Hurricane Harvey, Environ. Res. Lett., 14, 124023, https://doi.org/10.1088/17489326/ab5234, 2019.

Speer, J.: The Fundamentals of Tree-Ring Research, University of Arizona Press, Tucson, Arizona, 2012.

St. George, S.: An overview of tree-ring width records across the Northern Hemisphere, Quaternary Sci. Rev., 95, 132-150, https://doi.org/10.1016/j.quascirev.2014.04.029, 2014.

Stokes, M. A., and Smiley, T. L.: An Introduction to Tree-Ring Dating, The University of Arizona Press, Tucson, Arizona, 1968.

Stuiver, M., Burk, R. L., and Quay, P. D.: ${ }^{13} \mathrm{C} /{ }^{12} \mathrm{C}$ ratios in tree rings and the transfer of biospheric carbon to the atmosphere, J. Geophys. Res.-Atmos., 89, 11731-11748, https://doi.org/10.1029/JD089iD07p11731, 1984.
Szejner, P., Belmecheri, S., Ehleringer, J. R., and Monson, R. K.: Recent increases in drought frequency cause observed multi-year drought legacies in the tree rings of semi-arid forests, Oecologia, 192, 241-259, https://doi.org/10.1007/s00442-019-04550-6, 2020.

Tei, S., Sugimoto, A., Yonenobu, H., Matsuura, Y., Osawa, A., Sato, H., Fujinuma, J., and Maximov, T.: Tree-ring analysis and modeling approaches yield contrary response of circumboreal forest productivity to climate change, Glob. Change Biol., 23, 51795188, https://doi.org/10.1111/gcb.13780, 2017.

Therrell, M. D. and Bialecki, M. B.: A multi-century tree-ring record of spring flooding on the Mississippi River, J. Hydrol., 529, 490-498, https://doi.org/10.1016/j.jhydrol.2014.11.005, 2015.

TWDB: 2017 Texas State Water Plan, Texas Water Development Board, available at: http://www.twdb.texas.gov/ waterplanning/swp/2017/doc/SWP17-Water-for-Texas.pdf (last access: 9 February 2020), 2017.

USFWS: Draft Land Protection Plan Austin's Woods San Bernard National Wildlife Refuge Brazoria, Fort Bend, Matagorda and Wharton Counties Texas Texas Midcoast NWR Complex Draft Comprehensive Conservation Plan and Environmental Assessment, available at: https://www.fws.gov/southwest/refuges/plan/PDFs/TMC_ CCP_files/15_Appendix_I._LPP_Austins_woods_08-10-12.pdf (last access: 18 March 2020), 1997.

van Oldenborgh, G. J., van der Wiel, K., Sebastian, A., Singh, R., Arrighi, J., Otto, F., Haustein, K., Li, S., Vecchi, G., and Cullen, H.: Attribution of extreme rainfall from Hurricane Harvey, August 2017, Environ. Res. Lett., 12, 124009 , https://doi.org/10.1088/1748-9326/aa9ef2, 2017.

Vivian, L. M., Godfree, R. C., Colloff, M. J., Mayence, C. E., and Marshall, D. J.: Wetland plant growth under contrasting water regimes associated with river regulation and drought: implications for environmental water management, Plant Ecol., 215, 997-1011, https://doi.org/10.1007/s11258-014-0357-4, 2014.

Voelker, S., Meinzer, F., Lachenbruch, B., Brooks, J. R., and Guyette, R.: Drivers of radial growth and carbon isotope discrimination of bur oak (Quercus macrocarpa Michx.) across continental gradients in precipitation, vapor pressure deficit and irradiance, Plant Cell Environ., 37, 766-779, https://doi.org/10.1111/pce.12196, 2014.

Wang, H.-Q., Chen, F., Ermenbaev, B., and Satylkanov, R.: Comparison of drought-sensitive tree-ring records from the Tien Shan of Kyrgyzstan and Xinjiang (China) during the last six centuries, Adv. Clim. Change Res., 8, 18-25, https://doi.org/10.1016/j.accre.2017.03.004, 2017.

Wear, D. N. and Greis, J. G.: Southern forest resource assessment, Final Report Technical SRS-53, U.S. Department of Agriculture, Forest Service, Southern Research Station,Asheville, NC. 635 pp., available at: https://www.srs.fs.usda.gov/pubs/4833 (last access: 18 March 2020), 2002. 